http://garmian.edu.krd

https://doi.org/10.24271/garmian.151

\title{
Interaction effect of planting date and foliar application on some vegetative growth characters and yield of broccoli (Brassica olerasea var italica) grown under unheated plastic tunnel
}

\author{
Arshad A. Yaseen *, Sherwan J. Ahmed** \\ *Assistant Lecturer, Horticulture Dept., College of Agriculture, Salahaddin \\ University-Erbil, Erbil, Kurdistan Region, Iraq \\ ** Assistant Lecturer, Horticulture Dept., College of Agriculture, Salahaddin \\ University-Erbil, Erbil, Kurdistan Region, Iraq
}

\section{Abstract}

This study was conducted during autumn season of 2016 at Grdarasha research field, Agriculture College, Salahaddin University-Erbil, 434 meters above sea level to determine the effect of planting date and foliar application on the yield and some vegetative growth characters of broccoli. Seeds of Agassi F1 Hybrid broccoli cultivar were planted in the beginning of August 2016 then the seedlings were transplanted to unheated greenhouse in two different periods of time, the first was on 20th October and the second one was 20 days after the first transplanting dates which was on 10th November 2016. Foliar fertilizer PRO.SOL $(10+20+30)$ was also used with three levels (75g PRO.SOL/100 L water), (150g PRO.SOL /100 L water), (225g PRO.SOL /100 L water including control (0 g PRO.SOL/100 L water (spray with distilled water with factorial RCBD design). The result indicated that planting date significantly influenced some vegetative growth characters of broccoli and higher result was recorded for the total yield for seedlings transplanted in November. The average weight of main and secondary heads compared to the control, the main heads of the seedlings transplanted on 20th October produced highest yield while lateral heads recorded lower weight in compare to those transplanted on 10th November. However, the yield of the main heads recorded a better result for those grown in November. Foliar application had also significantly affected both yield and vegetative growth of broccoli. Seedlings sprayed with $150 \mathrm{~g} / 100 \mathrm{~L}$ water recorded the highest yield and vegetative growth. The interaction of foliar and time had a significant effect of the total yield and some vegetative growth at both times. The best result recorded at both times (October and November) and sprayed with $150 \mathrm{~g}$ of PRO.SOL/100 L water compare to the control (0 g PRO.SOL/100 L water) and the other foliar application levels.

Keywords: broccoli, unheated greenhouse, planting date, foliar application, vegetative growth, and total yield 


\section{INTRODUCTION}

Broccoli (Brassica oleraceae L. var italica) belonging to the family of Brassicaceae; Cruciferae which is a cool-season crop. The seedlings can tolerate the coldness; however, it does not tolerate frost in the early seedling stage of growth (before the plant has three or four pairs of true leaves). Early maturing varieties are more sensitive to low temperature damage than are those that mature later, the best growth condition is cool daytime temperatures $\left(21^{\circ}-29^{\circ} \mathrm{C}\right)$, lots of sun, and moist soil conditions. Growers need to provide the best possible growing conditions during the summer so that plants are the maximum possible vegetative size when head development starts, since the size of the plant limits the potential size of the head or curd (Vincent, et al., 2017). Broccoli is well known as a rich vegetable crop for its nutrient contents. Broccoli has merit as anticancer dietary measures due to having many protective elements in a cancer prevention diet include selenium, folic acid, vitamin B-12, vitamin D, chlorophyll, and antioxidants such as the carotenoids ( $\alpha$-carotene, $\beta$-carotene, lycopene, lutein, cryptoxanthin) mainly breast, colorectal, and prostate cancers, and even a 40-50 percent decrease in lung cancer, along with similar reductions in cancers at other sites (Michael S., 2004). It is also accounted as a good source of vitamin A, B2 and calcium (Sanders, 1996). Micro elements and nutrient like K. S. P. Mg have been found in broccoli buds (Aboul-Nasr and Ragab, 2000).

In Iraq, broccoli is still grown in a very limited scattered areas and the total cultivated area is not exactly known. In general, people are not familiar with the health benefits of the vegetable. Planting date is an important factor which can influence the total yield of the product (Hafiz et al., 2015). Broccoli is a new vegetable for Kurdistan region, Iraq; however, because of its nutritional value and taste acceptance, the demand for it is rapidly increasing. It is mostly grown in winter season in Iraqi Kurdistan region as an annual crop.

Fertilizer can impact the vegetative growth of broccoli such as plant height, leaves number, fresh and dry weight of leaves, stems, and apical heads (Abou El-Magd, et al., 2015).

Growing broccolis face some issues while growing in the soil mainly newly reclaimed soils the problems would be related to type of cultivars, fertilization, and irrigation, also chemical and biological properties of the soil (Abou El-Magd, et al. 2006; Abou El-Magd, et al. 2005). In addition, the suitable planting dates might be studied for increasing broccoli production. Broccoli is cultivated in Egypt mostly in around Cairo and Alexandria. Thus, many investigators dealt with planting dates in Egypt; however there is a very limited study on broccolis in Iraqi weather condition. The studies are mainly in Egypt and Bangladesh such research are (Emam, 2005; E 1-Hamd and Esmail, 2005; Abou El- Magd et al., 2006; Narendra 
Kumar et al., 2007; Preeti sighnal et al., 2009; Hanaa et al., 2010 and Hanaa, 2011; Abou El-Magd, 2013).

There are some other studies presenting the effect of NPK fertilization and foliar fertilization on broccoli plant. Therefore, this work was performed to evaluate some vegetative growth, heads yield, heads quality of Agassi F1 Hybrid broccoli cultivars under unheated greenhouse in two different transplanting times $20^{\text {th }}$ October and $11^{\text {th }}$ November treated with three levels of foliar fertilization.

\section{MATERIALS AND METHODS}

This study was carried out under unheated greenhouse conditions at Grdarasha agricultural research field/Agriculture college, Salahaddin University-Erbil, Latitude: $36.11 \mathrm{deg}$. N, Longitude: $44.00 \mathrm{deg}$. E, Altitude: 434 meters above sea level during fall season of 2016/2017.

This was to determine the effect of planting date and foliar application (fertilizer spraying) on the production (yield) and some vegetative growth of broccoli. Seeds of 'Agassi F1 hybrid' variety were planted in a field seedbed on the $28^{\text {th }}$ September 2016 and transplanted to unheated greenhouse at two different times, the first one was on the $20^{\text {th }}$ October 2016 and the second one 20 days after was on $10^{\text {th }}$ November 2016.

Factorial experiment was conducted using RCBD with 3 replications for the research layout with three replications. Each replicate consisted of a double row with a total of fourteen plants per plot. Plant spacing was $45 \mathrm{~cm}$ with a spacing of 1 $\mathrm{m}$ between the rows.

After transplanting the seedlings were irrigated with drip irrigation system, all the study units were only watered without adding any fertilizers to the soil. Mulching was also arranged for the plants to avoid or reduce the issue of weed competition. Around 20 days after transplanting, fertilizer of the formulation PRO.SOL $10+20+30$ was sprayed along the growing plants in one application. The broccoli plots were weekly sprayed. The fertilizers formulation was added based on the recommended amount 100-150 g of PRO.SOL/100 L water. The plots were irrigated with drip irrigation system which supplied water throughout the growing season. Plants sprayed three times during the growing season, 1st spraying applied after 2 weeks from transplanting, the second after 2 weeks from the first spraying and the third after the second spraying about 2 weeks.

In this study, the amount of foliar fertilizer was as follows:

Control treatment one: without fertilizer (only distilled water)

Treatment two: $75 \mathrm{~g}$ PRO.SOL/100 L water

Treatment three: $150 \mathrm{~g}$ PRO.SOL/100 L water

Treatment four: $225 \mathrm{~g}$ PRO.SOL/100 L water 


\section{Nutrient content of applied fertilizer:}

The fertilizer content was as follows:

Fertilizer contents: PRO.SOL 10+20+30

$10 \%$ Nitrogen

$20 \% \mathrm{P} 2 \mathrm{O}$

$30 \% \mathrm{~K} 2 \mathrm{O}$

$0.05 \%$ Boron

$0.10 \%$ Iron

$0.05 \%$ Magnesium (Mn)

$0.05 \%$ Cooper $(\mathrm{Cu})$

$0.0005 \%$ Molybdenum (Mo)

Name of Fertilizer: PROSOL 10+20+30

Manufactured by: PRO.SOL

Made in: Ozark Alabama 36361, USA

Recommended use and amount: foliar application at the rate of: 100-150g/100Lt

Imported company: Dabbana for modern agriculture

Production date: September 2014

Expire date: 3 years

The studied plant growth characters and yield included the following:

Plant height: $\mathrm{cm}$

Leaf length: $\mathrm{cm}$

Leaf width: $\mathrm{cm}$

Head weight (main and lateral head) $g$

Total yield (main and lateral head) $\mathrm{g}$

\section{The studied factors included:}

Time: October and November

Fertilizers $10+20+30$ PRO.SOL (control $0 \mathrm{~g}$ of PRO.SOL, $75 \mathrm{~g}$ of PRO.SOL, $150 \mathrm{~g}$ of PRO.SOL, 225g of PRO.SOL/100 L water)

\section{Data gathering:}

Harvesting for the main heads of the broccolis grown on $20^{\text {th }}$ October started when they reached to their optimum maturity on $10^{\text {th }}$ January about 70 days after transplanting the seedlings. Five heads were collected from each experimental unit. Then 18 days after harvesting the main heads, lateral heads also harvested based on their physical appearance. Only heads of marketable size were harvested. Leaves were stripped from the heads and the weights recorded. The main head weight was 
recorded including $12 \mathrm{~cm}$ of the bottom stem portion and $15 \mathrm{~cm}$ for the lateral heads. 20 days after harvesting the main heads the bud of the lateral heads began to sprout.

Number of side-shoots was recorded at the time when the lateral heads were collected. After all the mature leaves from the third node of the bottom of each broccoli was taken. Leaf length and width were recorded using a ruler across the vertical section of the leaves from the bottom to the top then leaf width also recorded from the middle of leaves horizontally. Weights of the main and lateral heads were recorded separately. Then both of them together to see the effect of transplanting time on the yield as well as vegetative growth. The yield for the foliar treatments was also measured in compare to the control.

The means were compared with Duncan multiple range at 0.05 using SPSS software version 23.

\section{Results and Discussions}

\subsection{Effect of foliar application on:}

\subsubsection{Vegetative growth and yield of broccoli:}

Table (1) shows the significant effect of the use of foliar fertilization on plant height and leaf length only. The highest values of them were recorded from the application of $150 \mathrm{~g} / 100 \mathrm{~L}$ water just below recommended level $(150 \mathrm{~g} / 100 \mathrm{~L}$ water) of fertilizer recorded the tallest plants in comparison to those treated with other levels and the control (untreated plants). In contrast, leaf width and number of side-shoots were not significantly difference with the foliar application treatments but similarly the more fertilizer was sprayed the means increased.

Table1. Effect of foliar application on plant height, leaf length, leaf width and number of side shoots.

\begin{tabular}{|l|c|c|c|c|}
\hline Foliar application & $\begin{array}{c}\text { Plant } \\
\text { height }\end{array}$ & $\begin{array}{c}\text { Leaf } \\
\text { length }\end{array}$ & $\begin{array}{c}\text { Leaf } \\
\text { width }\end{array}$ & $\begin{array}{c}\text { No. of side } \\
\text { shoots }\end{array}$ \\
\cline { 2 - 4 } & \multicolumn{3}{|c|}{$\mathrm{cm}$} \\
\hline $\begin{array}{l}\text { control 0 g/100L } \\
\text { water }\end{array}$ & $41.21 \mathrm{ab}$ & $63.08 \mathrm{~b}$ & $23.80 \mathrm{a}$ & $6.23 \mathrm{a}$ \\
\hline $75 \mathrm{~g} / 100 \mathrm{~L}$ water & $42.40 \mathrm{a}$ & $67.18 \mathrm{ab}$ & $24.10 \mathrm{a}$ & $5.93 \mathrm{a}$ \\
\hline $150 \mathrm{~g} / 100 \mathrm{~L}$ water & $43.16 \mathrm{a}$ & $69.43 \mathrm{a}$ & $24.95 \mathrm{a}$ & $5.53 \mathrm{a}$ \\
\hline $225 \mathrm{~g} / 100 \mathrm{~L}$ water & $39.07 \mathrm{~b}$ & $65.33 \mathrm{ab}$ & $24.03 \mathrm{a}$ & $5.567 \mathrm{a}$ \\
\hline
\end{tabular}

The treatments having the same letter or letters within the same column are not significantly different 
In general, mineral fertilizer increases vegetative growth of plants (Zaki, et al., 2012) and (Saad, 2013). It is important to add Potassium to plants since it is a necessary element in young growing tissues for cell elongation and possibly for cell division maintenance of torpor pressures well as some physiological processes and uptake of other nutrient elements (Sadanandan, et al., 2002).

Table 2 refers to the significant effect of foliar fertilization on weight of lateral and main heads and total yield foliar fertilizer had also influenced the weight of main and lateral heads. Foliar fertilizer had also affected the Weight of heads lateral or side shoots. Plants sprayed with $150 \mathrm{~g} / 100 \mathrm{~L}$ water recorded the heaviest head weight at $183.8667 \mathrm{~g}$ head -1 besides unfertilized plants recorded the lowest head weight. This result agreed with (Zaki, et al., 2015) were plants treated with potassium fertilizer and nitrogen recorded higher head weight.

Plants treated with $150 \mathrm{~g}$ PRO.SOL/100 L water recorded the heaviest weight of lateral shoot heads and main head at (231.8667 $\mathrm{g})$ and $(324.4000 \mathrm{~g})$ respectively; however there were a considerable decrease in the weight of (untreated) plants and the highest foliar application (225g PRO.SOL/100 L water).

Table 2: Effect of foliar fertilizer on Weight of main, lateral heads and total yield of broccoli

\begin{tabular}{|c|c|c|c|}
\hline Foliar application & $\begin{array}{c}\text { Weight of } \\
\text { main head }\end{array}$ & $\begin{array}{c}\text { Weight of } \\
\text { lateral head }\end{array}$ & Total yield \\
\cline { 2 - 4 } & \multicolumn{3}{|c|}{$\mathrm{G}$} \\
\hline $\begin{array}{c}\text { Control } 0 \mathrm{~g} / 100 \mathrm{~L} \\
\text { water }\end{array}$ & $263.79 \mathrm{~b}$ & $145.53 \mathrm{c}$ & $2046.61 \mathrm{c}$ \\
\hline $75 \mathrm{~g} / 100 \mathrm{~L}$ water & $303.53 \mathrm{~b}$ & $180.17 \mathrm{~b}$ & $2418.50 \mathrm{~b}$ \\
\hline $150 \mathrm{~g} / 100 \mathrm{~L}$ water & $350.00 \mathrm{a}$ & $207.87 \mathrm{a}$ & $2789.33 \mathrm{a}$ \\
\hline $225 \mathrm{~g} / 100 \mathrm{~L}$ water & $284.23 \mathrm{~b}$ & $144.50 \mathrm{c}$ & $2143.67 \mathrm{cb}$ \\
\hline
\end{tabular}

Numbers with the same letters are not significant different data analyses was Duncan ${ }^{\mathrm{a}, \mathrm{b}}$ multiple range

\subsection{Effect of transplanting time on:}

\subsubsection{Vegetative growth}

Table 3 shows that there is a significant difference in broccolis plant height, whereas leaf length, leaf width and number of side shoots were not affected significantly by transplanting date seedlings transplanted in October had a better vegetative growth than those transplanted in November. This might be due to some physiological problems because of unstable temperatures during plant formation. Temperature results in rapid growth of vegetative parts of broccoli plant (Kałużewicz et al., 2013). 
Table 3: Effect of transplanting time on the vegetative some of the growths of broccoli

\begin{tabular}{|c|c|c|c|c|}
\hline $\begin{array}{c}\text { Transplanting } \\
\text { time }\end{array}$ & $\begin{array}{c}\text { Plant } \\
\text { height }\end{array}$ & $\begin{array}{c}\text { Leaf } \\
\text { length }\end{array}$ & $\begin{array}{c}\text { Leaf } \\
\text { width }\end{array}$ & $\begin{array}{c}\text { No. of } \\
\text { side } \\
\text { shoots }\end{array}$ \\
\hline October & $67.87 \mathrm{a}$ & $25.07 \mathrm{a}$ & $25.07 \mathrm{a}$ & $6.47 \mathrm{a}$ \\
\hline November & $64.65 \mathrm{~b}$ & $23.38 \mathrm{a}$ & $23.38 \mathrm{a}$ & $5.17 \mathrm{a}$ \\
\hline
\end{tabular}

Note: Numbers with the same letters are not significant different data analyses was Duncan ${ }^{\mathrm{a}, \mathrm{b}}$ multiple range .

\subsubsection{Total yield}

Table 4 illustrated that weight of the main heads of broccoli significantly different for those transplanted in October and November. The heaviest main head was recorded in plants grown in November while the lateral heads recorded oppositely in compare to the seedlings transplanted in October. . However, the total yield was not significantly different for the seedlings transplanted in October and November. The highest result of total yield recorded in plants grown and formed their heads in November $(2438.17 \mathrm{~g})$ while the lower result was $(2260.89 \mathrm{~g})$ for the seedlings transplanted in October. The result was similar the result of (Kaluzewicz et al., 2013) which said that in the period of very rapid growth of leaf area, the broccoli head growth was the slowest lateral head weight.

Table 4: Effect of transplanting time on the weight of main and lateral heads and the total yield of broccoli

\begin{tabular}{|c|c|c|c|}
\hline $\begin{array}{c}\text { Transplanting } \\
\text { time }\end{array}$ & $\begin{array}{c}\text { Wight of } \\
\text { main } \\
\text { heads }\end{array}$ & $\begin{array}{c}\text { Weight } \\
\text { of } \\
\text { lateral } \\
\text { heads }\end{array}$ & $\begin{array}{c}\text { Total } \\
\text { yield }\end{array}$ \\
\cline { 2 - 4 } & \multicolumn{3}{|c|}{$\mathrm{g}$} \\
\hline October & $253.16 \mathrm{a}$ & $199.01 \mathrm{a}$ & $\begin{array}{c}2260.89 \\
\mathrm{a}\end{array}$ \\
\hline November & $347.62 \mathrm{~b}$ & $140.01 \mathrm{~b}$ & $\begin{array}{c}2438.17 \\
\mathrm{a}\end{array}$ \\
\hline
\end{tabular}

Note: Numbers with the same letters are not significant different data analyses was Duncan ${ }^{\mathrm{a}, \mathrm{b}}$ multiple range 


\subsection{Interaction effect of planting date and foliar fertilization on vegetative growth of broccoli}

\subsubsection{Vegetative growth}

\subsubsection{Plant height}

As it is shown in table 5, the obtained data revealed that the interaction treatments significantly affected on the plant height. Seedlings transplanted in October and November and sprayed with $150 \mathrm{~g}$ PRO.SOL /100 L water and $225 \mathrm{~g}$ PRO.SOL /100 L water had significantly different than other treatments at 47.31 and 37.26 respectively while others are not significantly different. This result was matched to other investigations that showed the similar results as (El-Magd, et al., 2015; Mona, et al., 2015).

\subsubsection{Leaf length and width}

Both of the leaf length and leaf width were affected by interaction of planting date and foliar application. Plants grown in October sprayed with $75 \mathrm{~g}$ of PRO.SOL/100 $\mathrm{L}$ water recorded the longest leaf length at $72.23 \mathrm{~cm}$ in contrast the shortest leaf length recorded on the plants grown in November treated with distilled water only at $62.00 \mathrm{~cm}$. Similarly, the widest leaf recorded on the plants grown in October sprayed with $75 \mathrm{~g}$ of PRO.SOL/100 L water at 26.07 while the narrowest leaf width was for the plants grown in November sprayed with $75 \mathrm{~g}$ of PRO.SOL/100 L water at $22.13 \mathrm{~cm}$. similar results recorded by El Hifny et al., (2002) and Vagen et al., (2004).

\subsubsection{Number of side shoots (lateral heads)}

Significantly effected were recorded in interaction of foliar application and planting date on the number of side shoots of the broccolis. The highest number was for control (untreated plants) and grown in November at 7.80 while the lowest number was for those grown in November and sprayed with75 g PRO.SOL/ $100 \mathrm{~L}$ water at 4.07.

Table 5: Combination effect of transplanting time and foliar spray on: plant height, leaf length, leaf width and number of side shoots.

\begin{tabular}{|c|c|c|c|c|}
\hline $\begin{array}{c}\text { Interaction } \\
\text { between } \\
\text { foliar and } \\
\text { time }\end{array}$ & $\begin{array}{c}\text { Plant } \\
\text { height }\end{array}$ & $\begin{array}{c}\text { Leaf } \\
\text { length }\end{array}$ & $\begin{array}{c}\text { Leaf } \\
\text { width }\end{array}$ & $\begin{array}{c}\text { No. of } \\
\text { side } \\
\text { shoots }\end{array}$ \\
\cline { 2 - 5 } a1b1 & $\begin{array}{c}39.95 \\
\mathrm{~cd}\end{array}$ & $64.17 \mathrm{~b}$ & $24.73 \mathrm{ab}$ & $6.73 \mathrm{ab}$ \\
\hline a1b2 & $\begin{array}{c}42.47 \\
\mathrm{bc}\end{array}$ & $62.00 \mathrm{~b}$ & $22.87 \mathrm{ab}$ & $5.73 \mathrm{bc}$ \\
\hline
\end{tabular}




\begin{tabular}{|c|c|c|c|c|}
\hline a2b1 & $\begin{array}{c}45.80 \\
\mathrm{ab}\end{array}$ & $72.23 \mathrm{a}$ & $26.07 \mathrm{a}$ & $7.80 \mathrm{a}$ \\
\hline $\mathrm{a} 2 \mathrm{~b} 2$ & $\begin{array}{c}39.00 \\
\mathrm{~cd}\end{array}$ & $62.13 \mathrm{~b}$ & $22.13 \mathrm{~b}$ & $4.07 \mathrm{c}$ \\
\hline $\mathrm{a} 3 \mathrm{~b} 1$ & $47.32 \mathrm{a}$ & $71.50 \mathrm{a}$ & $25.27 \mathrm{ab}$ & $5.53 \mathrm{bc}$ \\
\hline $\mathrm{a} 3 \mathrm{~b} 2$ & $\begin{array}{c}39.00 \\
\mathrm{~cd}\end{array}$ & $\begin{array}{c}67.37 \\
\mathrm{ab}\end{array}$ & $24.63 \mathrm{ab}$ & $5.53 \mathrm{bc}$ \\
\hline $\mathrm{a} 4 \mathrm{~b} 1$ & $\begin{array}{c}40.87 \\
\mathrm{~cd}\end{array}$ & $\begin{array}{c}63.57 \mathrm{~b} \\
24.20 \mathrm{ab}\end{array}$ & $5.80 \mathrm{c}$ \\
\hline $\mathrm{a} 4 \mathrm{~b} 2$ & $37.27 \mathrm{~d}$ & $\begin{array}{c}67.11 \\
\mathrm{ab}\end{array}$ & $23.87 \mathrm{ab}$ & $5.33 \mathrm{bc}$ \\
\hline
\end{tabular}

Numbers with the same letters are not significant different

a: foliar application

b: time of transplanting

b1: seedlings transplanted in October

b2: seedlings transplanted in November

data analyses was Duncan ${ }^{\mathrm{a}, \mathrm{b}}$ multiple range

\subsubsection{Main and lateral head weight}

Table 6 shows the interaction of foliar and transplanting time has caused a significant difference in the weight of main, lateral head weight. Plants grown in November and sprayed with $150 \mathrm{~g}$ PRO.SOL/100 L water have produced the heaviest main heads at $(375.60 \mathrm{~g})$ while the lowest head weight recorded for untreated plants grown in October at (187.24 g).

The heaviest lateral heads were recorded for the seedlings transplanted in October and sprayed with $150 \mathrm{~g}$ PRO.SOL/100 L water at 207.93g though the lowest lateral head weight recorded for seedlings transplanted in November sprayed with $0 \mathrm{~g}$ PRO.SOL/100 L water (distilled water) at (98.00) g.

The main heads of plants grown in October had the lower weight in comparison to those grown in November; however their lateral head weight recorded the higher result. Besides the heaviest main head weight were recorded in plants grown in November and sprayed with $150 \mathrm{~g}$ of PROSOL fertilizer/100 litter water at $375.6 \mathrm{~g}$ whereas the lowest head weight recorded in plants sprayed with $225 \mathrm{~g}$ of PROSOL fertilizer/100 litter water at $314.8 \mathrm{~g}$. the same for the plants grown in October, the heaviest main head were those sprayed with $125 \mathrm{~g}$ of PROSOL fertilizer/100 litter water at $324.4 \mathrm{~g}$ but the lowest head weight were recorded in control (plants sprayed with distilled water) at $187.2 \mathrm{~g}$. 


\subsubsection{Total head weight}

It can be seen from the table 6 the total yield has significantly influenced by the interaction of transplanting date and foliar application. Plants grown in October treated with the foliar applications $(0,75,150$ and 225$) \mathrm{g}$ of PRO.SOL/100 L water had the lower yield at 1901.55, 2276.67, 2781.33, 2084.00 in compare to those grown in November with the same amount of the sprayed fertilizer $(0,75,150$ and 225) $\mathrm{g}$ of PRO.SOL/100 L water) at 2191.67, 2560.33, 2797.33 and 2203.33 respectively.

Seedlings transplanted in November and sprayed with $150 \mathrm{~g}$ PRO.SOL/100 L water produced the largest yield at (2797.33) while those transplanted in October sprayed with distilled water recorded the lowest yield at (1901.55).

According to this result, seedlings transplanted in both October and November and sprayed with 150g PRO.SOL/100 L water have recorded the best result at 2781.33 and 2797.33 respectively while those transplanted in October and November and sprayed with only distilled water have resulted the lowest yield at 1901.55 and 2191.67 respectively.

The head weight for both lateral and main heads decreased its weight at different time of the growing season might be due to the influence of the warmer temperature. Kałużewicz, et al., (2010) have determined that besides the vegetative development warmer temperature can also influence yield and head quality of broccoli as well.

Table 6: Effect of interaction of planting time and foliar application on the weight of the main head, weight of the lateral head and the total yield of broccoli.

\begin{tabular}{|c|c|c|c|}
\hline \multirow{2}{*}{$\begin{array}{c}\text { Interaction } \\
\text { (foliar and } \\
\text { time) }\end{array}$} & $\begin{array}{c}\text { Weight of } \\
\text { main head }\end{array}$ & $\begin{array}{c}\text { Weight of } \\
\text { lateral head }\end{array}$ & Total yield \\
\cline { 2 - 4 } & \multicolumn{3}{|c|}{$\mathrm{g}$} \\
\hline $\mathrm{a} 1 \mathrm{~b} 1$ & $187.24 \mathrm{c}$ & $193.07 \mathrm{abc}$ & $1901.55 \mathrm{c}$ \\
\hline $\mathrm{a} 1 \mathrm{~b} 2$ & $340.33 \mathrm{a}$ & $98.00 \mathrm{f}$ & $2191.67 \mathrm{bc}$ \\
\hline $\mathrm{a} 2 \mathrm{~b} 1$ & $247.40 \mathrm{bc}$ & $207.93 \mathrm{ab}$ & $2276.67 \mathrm{bc}$ \\
\hline $\mathrm{a} 2 \mathrm{~b} 2$ & $359.67 \mathrm{a}$ & $152.40 \mathrm{de}$ & $2560.33 \mathrm{ab}$ \\
\hline $\mathrm{a} 3 \mathrm{~b} 1$ & $324.40 \mathrm{a}$ & $231.87 \mathrm{a}$ & $2781.33 \mathrm{a}$ \\
\hline $\mathrm{a} 3 \mathrm{~b} 2$ & $375.60 \mathrm{a}$ & $183.87 \mathrm{bcd}$ & $2797.33 \mathrm{a}$ \\
\hline $\mathrm{a} 4 \mathrm{~b} 1$ & $253.60 \mathrm{bc}$ & $163.20 \mathrm{de}$ & $2084.00 \mathrm{bc}$ \\
\hline $\mathrm{a} 4 \mathrm{~b} 2$ & $314.87 \mathrm{ab}$ & $125.80 \mathrm{ef}$ & $2203.33 \mathrm{bc}$ \\
\hline
\end{tabular}

Means were compared using Duncan multiple range

Note: Numbers with the same letters are not significant different a: foliar application 
b: time of transplanting

b1: seedlings transplanted in October

b2: seedlings transplanted in November

Figure (1) illustrates that seedlings transplanted on $20^{\text {th }}$ October produced heaver main heads whereas lateral heads were recorded minor weight in compare to those transplanted 20 days later. In contrast, broccolis transplanted on $10^{\text {th }}$ November produced bigger and heaver main head but lighter lateral head weight. This result agreed to other researches that have been shown the impact of time on broccoli yield and quality characteristics of broccoli (Thirupal, et al., 2016). The highest mean for the total yield was recorded for those transplanted in November, mainly seedlings treated with $150 \mathrm{~g}$ of PRO.SOL/100 L water at 2797.33.

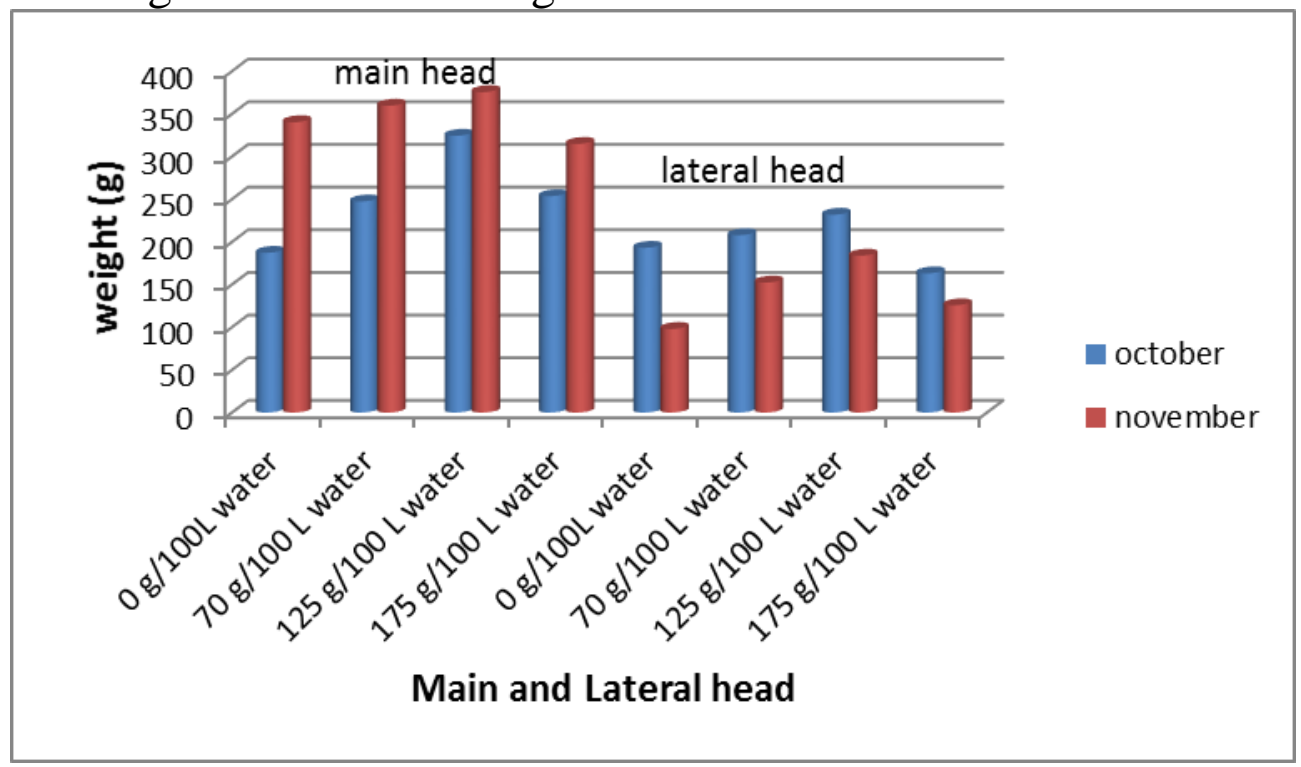

Figure1. Combined effect of time of transplanting and foliar application on weight of broccoli heads (main and lateral).

Results show that October transplanting of broccoli seedlings with the amount of $150 \mathrm{~g}$ of PRO.SOL foliar fertilizer is the optimum result for the main heads and the total yield. This result agrees with (Hossain, et al., 2011) which indicated that 15th October is ideal of broccoli production.

Plants grown in October produced the heaviest lateral shoots but lower main heads in comparison with those grown in November this was due to the temperature. Since broccoli is a cool season crop it is best to grow and produce better yield so that after the main heads removed the lateral heads started to grow and the weather were getting cold in contrast the main heads of plants grown in November were best grown because of the cold weather but the lateral heads was harvested while the temperature were increased in March in compare to December and January. In order to achieve additional results on the 'Agassi F1 hybrid' variety, further investigation is recommended to be taken into consideration mainly transplanting 
date. It is recommended that Agassi F1 hybrid be grown in earlier season as well to see the differences in the total yield. This might be useful if it will be grown in both open field and greenhouse to see the characteristics in both environments such as quality and the total yield. Regarding foliar fertilizer, we do recommend to use 150 $\mathrm{g}$ of PROSOL fertilizer/100 litter water since this was the best treatment for this research. For the fall season we strongly recommend that Agassi F1 Hybrid transplant to unheated plastic tunnel in the earlier time in order to get enough temperature for the beginning of the growing season and enough coldness when the heads produce. The later transplanted seedlings the higher risk plants will face with warm temperature in March.

\section{Conclusions}

In general, plants grown in November recorded the lowest values of the vegetative growth parameters than those grown in October. In contrast, the best result for the total yield recorded for the seedlings transplanted in November. The interaction of foliar application and transplanting date resulted in some significantly difference for both of the vegetative growth and the total yield. The best result was for seedlings transplanted in November with $150 \mathrm{~g} / 100 \mathrm{~L}$ water spray.

\section{Acknowledgements}

The author would like to send a special thanks to professor Dr. Akram Othman Esmail for all his efforts.

\section{References}

Abou El-Magd M.M., Zaki, M. F, and Abou Sedera2 S. A. (2015) Growing Two Broccoli Cultivars Under Different Mineral And Foliar Fertilization Treatments. Journal of Innovations in Pharmaceuticals and Biological Sciences 2.4: 620-631.

Abou El-Magd, M. M.; A. M. El-Bassiony and Z. F. Fawzy (2006) Effect of organic manure with or without chemical fertilizers on growth, yield and quality of some varieties of broccoli plants. Journal of Applied Sciences Research, 2 (10): 791-798.

Abou El-Magd, M. M.; Hoda, A. Mohamed and Z. F. Fawazy (2005) Relationship growth, yield of broccoli with increasing $\mathrm{N}, \mathrm{P}$ or $\mathrm{K}$ ratio in a mixture of NPK fertilizers (Brassica oleracea var. italica plenck). Annals of Agric. Sc., Moshtohor, 43 (2): 791-805. 
Abdul-Nasr, M.H. and W.S.M. Ragab, 2000. Yield, head quality and nutritional composition of a new late flowering broccoli variety grown under Assiut conditions. Assiut Journal of Agricultural Science. 31(1): 55-77.

Damato, G., 2000. Late sowing dates and high plant density in six cultivars of broccoli for processing. Acta Horticulture., 533: 267-274.

El-Hifny, I.M., M.M.F. Abdallah and S.S. Gomaa, (2002) Influence of sowing date, production method and cultivars on broccoli transplants production. Arab Universities Journal of Agricultural Science. 10(3): 867-877.

Hafiz M. A., A. Biswas, M., Zakaria, J. Hassan, and N. A. Ivy (2015) Effect Of Planting Dates On The Yield Of Broccoli Genotypes. Bangladesh J. Agril. Res. 40(3): 465-478

Hossain MF, Ara N, Uddin MR, Dey S and Islam MR (2011) Effect of time of sowing and plant spacing on broccoli production. Tropical agricultural research \& extension 14(4): 90-92

Kałużewicz A., Krzesiński W., Knaflewski M. Lisiecka J., Spiżewski T. and Frąszczak B. (2010). The effect of temperature on the broccoli yield and length of the period from head initiation to harvest. Acta Sci. Pol. Hortorum cultus 9: 167174.

Kałużewicz A., Krzesiński W., Knaflewski M., Lisiecka j., Spiżewski T., and Frąszczak B., (2013) 'effect of temperature on the growth of broccoli (brassica oleracea l. var. italica plenck) cv. fiesta', Dąbrowskiego Poznań, Poland, 77(2012), pp. 129-141.

Michael S, Donaldson, 2004. Nutrition and cancer: A review of the evidence for an anti-cancer diet. Nutritional Journal, [Online]. 3:19, 1-21. Available at: https://nutritionj.biomedcentral.com/articles/10.1186/1475-2891-3-19 [Accessed 18 July 2017].

Mona, E.E. and M.M. AbouEl-Magd (2015) Onion yield and quality as affected by some complementary foliar fertilizers. European Journal of scientific research.; Vol. 128 No 2 January, pp: 121-133.

Saad, M. Howladar; Mostafa, M. Rady and Ashraf, S. Osman, 2013. Effect of bionitrogen as a partial alternative to mineral-nitrogen fertilizer on growth, nitrate and nitrite contents and yield quality In Brassica oleracea L. International Journal of Agricultural Science and Engineering, 7(7): 482-487. 
Sadanandan, A. K.; K. V. Peter and S. Hamza, (2002) Role of potassium nutrition in improving yield and quality of spice crops in India. Haryana and International Potash Institute, Switzerland, pp: 445- 454.

Sanders, D.C., 1996. Broccoli production .Leaflet NO.5,NC cooperative extension service.

Thirupal, G. Narayana Swamy1 , M. Ravi Venkanna Babu1 And A. Kireeti. (2016) Standardization of optimum time planting on broccoli production. THEASIAN JOURNAL OF HORTICULTURE. 11 (1): 72-74

Vagen, I.M., A.O. Shjelvag and H. Bonesmo, (2004) Growth analysis of broccoli in relation to fertilizer nitrogen application. Journal of Horticultural Science and Biotechnology, 79 (3): 484- 492.

Vincent A. Fritz, Carl J. Rosen, Michelle A. Grabowski, William D. Hutchison, Roger L. Becker, Cindy B.S. Tong, Jerry A. Wright and Terry T. Nennich. (2017). Growing broccoli, cabbage and cauliflower in Minnesota. [ONLINE] Available at: https://www.extension.umn.edu/garden/yard-garden/vegetables/growing-broccolicabbage-and-cauliflower-in-minnesota/. [Accessed 18 July 2017].

Zaki, M. F.; A. S. Tantawy; S. A. Saleh and Yomna I. Helmy, 2012. Effect of biofertilization and different levels of nitrogen sources on growth, yield components and head quality of two broccoli cultivars. Journal of Basic and Applied Science Research, 8 (8): 3943 - 3960. 